\title{
A STUDY ON THE INFLUENCE OF FAMILY ON FAMILY BUSINESSES AND ITS RELATIONSHIP TO SATISFACTION WITH FINANCIAL PERFORMANCE
}

\section{Evren Ayranci}

\section{Introduction}

Family businesses comprise one of today's most important types of businesses. The family-business interconnectedness consists of several components, as members of the family must fulfill many roles in the business such as owner, manager, and employee. An additional component that family businesses must also address is that of cultural relations.

Based on the aforementioned components, it is expected that family can bias the business, that is, family can influence the course of the business. This expectation is among the points that have been considered in this article. It is certainly possible that family members can influence the business, particularly in the role of manager or owner of the business; however, the influence is generally the result of a combination of several factors rather than a single factor. To state it more clearly, the influence of family on business is the result of a combination of various factors, such as ownership, management, institutionalization, succession relationships, similarities between familybusiness values, contributions of the family to the business, experience of the family with respect to business issues, and the influence of the founder, successor, and spouses. It is necessary to adopt an approach that can be used scientifically and that considers all of these components. A similar approach has been reported in the literature review, an approach that this article has also utilized.

Based on a survey of the literature, it was determined that the focus of this study should also cover the financial performance of the family-owned business. However, with the assumption that it would be difficult to obtain financial data, this article discusses how satisfied the top manager family member is with the financial performance of the business.

Subjects of discussion include the "influence of family" and "satisfaction of the top manager family member with the financial performance of the business," along with the relationship between these two concepts. The aim of this article was to explore the relationship between these two concepts. Toward this goal, research was conducted on family businesses within the organized industrial zones (OIZs) of Istanbul, Turkey. The purpose of the research was to establish the existence of a relationship between the influence of family on its business and the satisfaction of the top manager family member with the business's financial performance.

The article begins by presenting a brief definition of a family business based on specific criteria. After considering the various definitions for the influence of family on its own business, some conclusions are deduced from the various studies in the literature that either explicitly or implicitly define the role of family in the business. Based on these deductions, a general definition is provided for the concept of family influence and the components that constitute family influence. The family - power, experience, and culture (F-PEC) scale is introduced as a scale that considers some of the aforementioned components. The F-PEC scale was developed as an instrument to assess the influence of family on a family business, although other 
factors are considered regarding family influence. After describing satisfaction with financial performance as a main concept, a pilot study was conducted that illuminates the statistical structures of the two concepts: family influence and satisfaction with financial performance. The relationship between the two structures revealed from the scope of research was investigated, and the conclusions reached are presented. Few studies in the extant literature address and investigate the concept of family influence. Therefore, this article not only contributes to the few existing studies on this subject but also adds to the international literature on the current status of family businesses in Turkey with respect to this subject.

\section{Definitions of the Family Business Concept}

To better understand the concept of family business, the studies conducted thus far on family businesses may be briefly reviewed. The number of scientific studies related to familyowned businesses began to increase in the 1970s. A curious observation is the presence of high-quality international scientific sources on this theme. Good examples of these sources are provided by two journals: the Family Business Review and the Electronic Journal of Family Businesses. In Turkey, conversely, contributions to the literature on family businesses come primarily from scientific sources, such as theses and dissertations, although there are organizations that investigate family businesses, such as the Family Businesses Congress that is held biennially. When these sources are evaluated collectively, family businesses are found to be defined by many approaches. The foremost concept considers the family members as owners or managers of the business when defining the concept of the family business. For example, Barnes and Hershon [10] considered that a family business is one in which complete control of the business is in the hands of a particular family, whereas Donckels and Fröhlich [23] stipulated that a family business is one in which a family owns at least a $60 \%$ share of the business. Ward and Dolan [58], conversely, stipulated that a familyowned business is one in which the family has a majority of the votes in business decisions. Meanwhile, Barry [11], leaning toward the concept of management, employed a more generalized approach and asserted that a business can be called a family business as long as the family manages the business. Rue and Ibrahim [48] argued that a family business is one in which the family has the majority vote in the management of the business, whereas McConaughy et al. [44] insisted that in a family business, the top manager must also be either the founder of the business or a descendent of the founder.

Based on the most general concept presented in the extant literature on the subject, any interaction between the family and the business is sufficient to render a business a family business. An excellent example is provided by Davis [20], who defined the family business as a structure with the presence of interactions between family and business clusters. According to Shanker and Astrachan [51], who provided yet another definition for family business, the low- or high-level employment of more than one family member by the business combined with the ability of these members to influence business activities are a prerequisite for a business to be regarded as a family business.

In yet another set of definitions of a family business, a combination of more detailed criteria is used. Dannhaeuser [19], for example, offered a definition in the context of three criteria: the business is composed of at least two family members who have ownership and/or managerial titles in the business, a majority of the family income comes from the business, and no more than 50 people are employed by the business. From a similar point of view, Anderson and Reeb [4] provided three conditions that must be met for a business to be considered a family business. First, the family should own shares of the business. Second, family members should be members of the management, governance, and/or advisory boards of the business. Third, the business should be actively managed by the founder or a first-degree relative of the founder.

As evidenced, a number of credible definitions and interpretations of what constitutes a family business are available. As mentioned previously, those studies that consider ownership and management criteria outweigh other studies in the literature. For the purpose of this study, a family business is one in which the members of a family make the majority 
(more than $50 \%$ ) of the business decisions and/or they hold a majority (more than $50 \%$ ) of the capital.

\section{Family Influence and Components That Underlie This Influence}

Studies that address the influence of the family on its own business or that somehow implicitly accept the existence of such an influence were reviewed, and inferences were made. Based on these inferences, the influence of a family on its business can be evaluated in terms of several topics or in the context of the family members. This includes topics related to the management and ownership of the business by the family and the influence of the prominent members of the family, such as the founder of the business, the successors, and/or the spouses, as well as the institutionalization of the family business. Once several studies that address the concept of family influence (e.g. [2], [9], [17], [22], [57]) are summarized, a general definition for the influence of family, that is, the ability of family members to influence the outcome of any business-related topics by their decisions and behavior can be proffered.

It is understood that in a family business, family members will influence the business. This is especially true if the owner or manager of the business is also a member of the family. In other words, the aforementioned concept accepts the general opinion that family manages and owns the business, and hence, whatever the family says in family business matters will be accepted. In studies that employ this concept, family ownership and/or management of the business are considered to distinguish family businesses from other businesses or to convey that the family has the power to lead its own business (e.g. [3], [4], [9], [18], [44], [50], [60]).

The influence of family should also be considered in the context of agency relationships. In family businesses, the cost of transferring power to managers is nominal because the managers are already members of the family and they have ownership status. Furthermore, the strong emotional links between family members prevent managers in the family from being manipulative at the expense of harming other members of the family [50]. However, one must also consider that as more nonfamily member managers are engaged in the management of the business, the cost of transferring power to managers increases [5]. Based on this view, as opposed to the managers who are not members of the family, family member managers are more inclined to support the interests of the family who operates and owns the business. Furthermore, family member managers tend to be more selfless [13] as they are rarely motivated by financial incentives [18], thus, in this context, family businesses managed by the family can be more effective and productive when compared to nonfamily businesses [15].

Certain studies in the literature consider the effect that family influence can have on the business, that is, the influence of the family member who founded the business (founder), the family member who will take over the business (successor), and/or the spouses of the family members are emphasized. Studies that consider the influence of the founder of the business (e.g. [7], [52]) suggest that the founder has a strong influence on social aspects of the business, such as business culture, business objectives, and transaction methods. The successor, conversely, is already able to influence the business with his or her title as successor. The successor is also able to obtain shares from business activities by initiating employment at any position in the business [25], [26]. In time, the successor can become sufficiently qualified to take control of various business issues as he or she acquires knowledge and experience and subsequently increases his or her role in business activities [40], [46], [56]. In family businesses that have a succession plan in place, the power given to the successor is steadily increased, and the successor therefore becomes a higher-level decision maker in crucial business issues [16], [28]. In family business, spouses of members of the family provide both tangible and intangible contributions to business issues [27], [41], [42], [47], and, in certain situations, they even have decision-making power [37]. Consequently, disagreements between spouses can also adversely affect the business [24].

The institutionalization of the business should be considered together with the influence of the family. In particular, studies in Turkey that address the institutionalization of family businesses evaluate institutionalization as a transition of the business to a professional 
management platform [8], the development of new work models [14], and the formation of family constitutions and family councils [1]. As a result, on the one hand, institutionalization is associated with the concept of management, whereas on the other hand, it consists of the regulation of relationships between family members and the business via the family constitution [36], as well as the shaping of the future of the business by the family via the family council [35]. Thus, it is logical to consider the possibility that all of these issues illustrate how the family influences the business.

The degree of satisfaction that the top manager family member has with the financial performance of the business is a primary concern in this study. In this context, it is appropriate to determine the extent to which the family can participate in financial decisions, as this participation may influence the financial outcomes of the business and, hence, the relative level of satisfaction the manager experiences with respect to the financial performance of the business. After a review of the literature (e.g. [43], [59]), a conclusion was reached with respect to the importance of investigating the extent of participation of the family in decisions that influence the sales volume (amount), revenue, operation profitability, net profit, return on investments (ROI), reduction of debt, short-term debt, and cash flow of the business. However, in research in this area, data are usually collected from the top manager family member. If this family member is included with the rest of the family when making financial decisions, then family participation, as a whole, will appear to have more direct influence than it actually has. In other words, the top manager family member already has the final word in all financial decisions. As a result, this research considers all family members other than the top manager member of the family when considering the participation of family members in financial decisions.

In the context of family influence, some of the components within the F-PEC scale, which is known in the literature as an overall measure of family influence, are also considered. The first dimension of the F-PEC scale, originally proposed by Astrachan et al. [6], is power, a dimension that reflects the overall contribution of the family members to ownership, management, and governance. The second dimension is experience. This dimension indicates which generation(s) of the family serve(s) as managers or owners of the business and how many family members are a part of the business, as well as the level of experience they bring to the business. The final dimension of the F-PEC scale is culture. This dimension includes the interplay between family and business value judgments and the interpersonal factors related to moral character, pride, harmony, and loyalty.

The F-PEC scale was validated in 2005 in a study of approximately 1,300 businesses. The study, incorporating both exploratory factor analysis (EFA) and confirmatory factor analysis (CFA) [38], concluded that the F-PEC scale was a valid and reliable measuring instrument. In addition, some studies have utilized part or all of this scale and included family businesses from different countries (e.g. [2], [9], [22]).

In summary, according to the literature, influence of family on its business is based on different components, such as the dimensions of F-PEC, as well as the influence of the founder, the successor, and the spouses. The author posits that components other than these, including institutionalization, agency relationships, and participation of the family in financial decisions, should also be considered under the umbrella of family influence.

\section{Satisfaction with Financial Performance}

In general terms, performance can be defined as an expression of how well individuals, groups, or organizations that perform a task attain their planned targets [12] or returns, as a whole, with respect to a given issue [45]. When the financial dimension is included, performance can be considered as sources of funds generated from the operations of a business performed during a certain period or the monetary value of returns from the policies and operations of a business. The concept of satisfaction can be defined as the emotion or feeling a person experiences when specific needs, expectations, or wants are met [53].

As stated earlier, this research addresses the satisfaction felt by the top manager family member toward the financial performance of his business. Thus, the author defines satisfaction with financial performance specific to this article as follows: how content a person is with the financial aspects of the business based on 
the difference between the proceeds of a family business (or financial outcomes) and what the top manager family member expects as proceeds (targeted outcome for the business).

Within the family influence, participation in eight decisions (namely; the sales volume or amount, revenue, operation profitability, net profit, return on investments (ROI), reduction of debt, short-term debt, and cash flow of the business) that can influence the financial outcomes of the business is considered. In this context, satisfaction with financial performance is therefore based on these eight components.

\section{Methodology}

\subsection{Universe, Sample, and Data Collection Method}

The research for this study was completed in two steps. A pilot study was conducted first to form the statistical structure of family influence and satisfaction with financial performance concepts, followed by an investigation of the relationship between the influence and satisfaction using these statistical structures via a relationship model. Figure 1 shows this model in a closed form. Once the pilot study revealed statistical structures of influence and satisfaction, more details to be considered were indicated.

\section{Fig. 1: The Relationship Model}

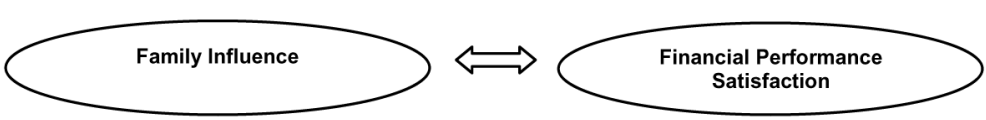

Source: Adapted by the author based on the literature mentioned in sections 3 and 4 .

Tab. 1: OIZs in Istanbul according to the Higher Council of Organized Industrial Zones

\begin{tabular}{l|c} 
Name of OIZ & Total Number of Businesses \\
\hline Ikitelli & $3486[29]$ \\
\hline Istanbul Leather & $42[32]$ \\
\hline Istanbul Tuzla & $67[33]$ \\
\hline Istanbul Tuzla Chemical Enterprises & $167[39]$ \\
\hline Tuzla Marble Businesses & $113[55]$ \\
\hline Istanbul Tuzla Paint and Lacquer & $50[34]$ \\
\hline Beylikduzu & $690[30]$ \\
\hline Dudullu & $147[31]$ \\
\hline TOTAL & 4762 \\
\hline
\end{tabular}

Source: own (formed by the data collected from OIZs' web sites)

Note: $\quad$ IKITELLI OIZ. Firm guide. http://www.iosb.org.tr/v2/firmalar.xls March 42011.

ISTANBUL LEATHER OIZ. Firm catalogue. http://www.ideriosb.org.tr/index.php?option=com_sobi2\&ltemid=18 March 42011.

ISTANBUL TUZLA OIZ. The list of all firms. http://www.itosb.org.tr/tumfirma.htm March 42011.

KOBIEFOR. Tuzla chemical enterprises. http://www.kobi-efor.com.tr/haber_detay.asp?id=2647 March 42011. TUZLA MARBLE OIZ. Tuzla marble OIZ active firms. http://www.tmosb.com/dosyalar/faalliste.xls March 42011. ISTANBUL TUZLA PAINT AND LECQUER OIZ. Firms. http://www.boyavernikosb.com/firmalar.htm March 42011. ISTANBUL BEYLIKDUZU OIZ. Firms. http://www.ibosb.com/TR/firm March 42011.

ISTANBUL DUDULLU OIZ. Enterprizes in the zone. http://www.idosb.org.tr/bolgedekikuruluslar.asp, March 42011. 
For both the pilot study and the testing of the relationship model, data were collected from family businesses located within the OIZs of Istanbul, Turkey. Research was conducted to identify the types of OIZs in Istanbul. The list of OIZs published by the Higher Council of Organized Industrial Zones [54] was used. Table 1 shows the distribution of the total number of businesses, according to the OIZs.

From Table 1, there are a total of 4,762 businesses; however, it is not known how many of these businesses meet the criteria to be considered family businesses. In the data collection, businesses that fit the description of a family business as defined by the author under the heading of definitions of the family business concept were accepted as family businesses. When the sample size was calculated and all businesses were considered, the margin of error was assumed to be $5 \%$, whereas the confidence level was assumed to be $95 \%$. It was determined that 356 family businesses are required for data collection. It was considered that there may be missing data in the list of businesses and that some data may have contained incorrect answers that will result in a reduction of the sample size by wastage, which was calculated at $15 \%$ of the total data. To compensate for this loss, an additional $15 \%$ of 356 businesses were added to the original 356 businesses, resulting in a total of 410 businesses from which to gather data. To test the relationship model, businesses from each OIZ in Table 1 were selected relative to the number of businesses in each OIZ by the quota sampling method. For the pilot study, a total of 100 family businesses from all OIZs in Table 1 were used in the data collection, and these businesses were recorded to prevent further use in data collection in the scope of this research.

A survey was used as a means of collecting data for both the pilot study and the testing of the relationship model. The definition of family businesses as previously provided by the author was written on the front page of the survey along with an explanation stating that only businesses that fit this definition were to be considered further. The attendees were asked whether their businesses fulfill the family business definition given. Steps were taken to ensure that the person who completed the survey from each business was the top manager family member. The questionnaire used in the pilot study evaluated family influence in four main parts including the F-PEC scale, institutionalization, agency relationships, and the possible effects of founders, successors, and spouses.

\subsection{Results of the Pilot Study}

As stated in the previous section, the purpose of the pilot study was to investigate statistical structures of the concepts that were addressed. To shed light on these structures, data collected by the mentioned questionnaire were considered.

Twenty-five variables remain from the results of the EFA performed on the family influence variables included in the pilot study. From the analysis, the Kaiser-Meyer-Olkin (KMO) value was 0.684 , whereas the Bartlett test value was significant at 0.05 level. Therefore, it is suitable to use factor analysis on the variables. Five factors were obtained for a total variance explained of $59.13 \%$. These factors and their relevant variables are shown in Table 2.

Cronbach's alpha values from the reliability analysis of the obtained factors and their variables were as follows: Family Participation in Financial Decisions: 0.855; Loyalty to and Harmony with the Business: 0.812; Influence of the Spouses: 0.822; Influence of the Successor: 0.713; Influence of the Founder: 0.759 ; and all variables of the factors: 0.736 .

These five factors under family influence and their variables were obtained on the basis of the results from literature searches. However, some questions remain as to whether these factors can be included under the roof of family influence. As a result, factor modeling including these five factors and a structural equation model (SEM) were used. A detailed modeling of family influence is displayed in Figure 2. 
Tab. 2: Results of the exploratory factor analysis for family influence variables

\begin{tabular}{|c|c|c|c|}
\hline Family Participation In Financial Decisions & $\begin{array}{l}\text { Factor } \\
\text { Weight }\end{array}$ & Loyalty to and Harmony with the Business & $\begin{array}{l}\text { Factor } \\
\text { Weight }\end{array}$ \\
\hline $\begin{array}{l}\text { Participation in decisions that affect the } \\
\text { operation profitability of the business. } \\
\text { (Partic_op) }\end{array}$ & 0.801 & $\begin{array}{l}\text { Our family members have similar family values. } \\
\text { (Sim_fam_val) }\end{array}$ & 0.811 \\
\hline $\begin{array}{l}\text { Participation in decisions that affect the regular } \\
\text { cash flows of the business. (Partic_flow) }\end{array}$ & 0.747 & $\begin{array}{l}\text { As a family, we reach a consensus on goals } \\
\text { and plans of the business. (Consen_plan) }\end{array}$ & 0.799 \\
\hline $\begin{array}{l}\text { Participation in decisions that affect the net } \\
\text { profit of the business. (Partic_prof) }\end{array}$ & 0.747 & $\begin{array}{l}\text { We are proud to say that we are part of our } \\
\text { family business. (Part_pride) }\end{array}$ & 0.706 \\
\hline $\begin{array}{l}\text { Participation in decisions that affect the sales } \\
\text { revenue of the business. (Partic_rev) }\end{array}$ & 0.743 & $\begin{array}{l}\text { All members of our family are willing to put in } \\
\text { more effort than expected of them to make } \\
\text { our business succeed. (Fam_effort) }\end{array}$ & 0.634 \\
\hline $\begin{array}{l}\text { Participation in decisions that affect the } \\
\text { short-term debt of the business. (Partic_sh_debt) }\end{array}$ & 0.739 & $\begin{array}{l}\text { As a family, we defend our business to others } \\
\text { during conversations. (Fam_defend) }\end{array}$ & 0.619 \\
\hline $\begin{array}{l}\text { Participation in decisions that affect all debt } \\
\text { reduction activities of the business. } \\
\text { (Partic_all_debt) }\end{array}$ & 0.668 & $\begin{array}{l}\text { We have similar business values as a family } \\
\text { and business. (Sim_bus_val) }\end{array}$ & 0.607 \\
\hline $\begin{array}{l}\text { Participation in decisions that affect the ROI } \\
\text { of the business. (Partic_ROI) }\end{array}$ & 0.631 & $\begin{array}{l}\text { As a family, we are loyal to our business. } \\
\text { (Loyal) }\end{array}$ & 0.586 \\
\hline Influence of the Spouses & $\begin{array}{l}\text { Factor } \\
\text { Weight }\end{array}$ & Influence of the Successor & $\begin{array}{l}\text { Factor } \\
\text { Weight } \\
\end{array}$ \\
\hline $\begin{array}{l}\text { Spouses of the family members within the } \\
\text { business are also expected to contribute to the } \\
\text { business by participating in the business. } \\
\text { (Spouse_partic) }\end{array}$ & 0.861 & $\begin{array}{l}\text { A succession plan detailing how, when, and } \\
\text { under what conditions to transfer the power } \\
\text { of the business to the next generation should } \\
\text { be implemented early. (Suc_plan) }\end{array}$ & 0.790 \\
\hline $\begin{array}{l}\text { Ideas from spouses of the managerial family } \\
\text { members on business operations are regarded } \\
\text { as natural and are welcome. (Spouse_idea) }\end{array}$ & 0.856 & $\begin{array}{l}\text { We pay close attention to the behavior of the } \\
\text { successor toward our business and our } \\
\text { employees. (Suc_beh) }\end{array}$ & 0.759 \\
\hline $\begin{array}{l}\text { When a family member gets married, the } \\
\text { spouse is incorporated into the business } \\
\text { structure. (Spouse_mar) }\end{array}$ & 0.846 & $\begin{array}{l}\text { The successor can control business issues. } \\
\text { (Suc_contrib) }\end{array}$ & 0.689 \\
\hline $\begin{array}{l}\text { Arguments between spouses of the family } \\
\text { members within our business adversely affect } \\
\text { our business. (Spouse_contrib) }\end{array}$ & 0.606 & $\begin{array}{l}\text { Employment of our family members in our } \\
\text { business at an early age is a good approach. } \\
\text { (Suc_early) }\end{array}$ & 0.636 \\
\hline Influence of the Founder & $\begin{array}{l}\text { Factor } \\
\text { Weight }\end{array}$ & & \\
\hline $\begin{array}{l}\text { Our family still maintains the goals set forth by } \\
\text { the founder for our business. (Found_goal) }\end{array}$ & 0.794 & & \\
\hline $\begin{array}{l}\text { The general world view of the founder of our } \\
\text { business has a strong effect on our business. } \\
\text { (Found_view) }\end{array}$ & 0.782 & & \\
\hline $\begin{array}{l}\text { Processes such as hiring, promotions, the } \\
\text { rewards/merit system, or firing are performed } \\
\text { as requested by the founder. (Found_process) }\end{array}$ & 0.770 & & \\
\hline
\end{tabular}

Source: own (calculations performed upon the data collected from OIZs mentioned in Table 1) 


\section{Ekonomika a management}

\section{Fig. 2: The detailed modeling of family influence}

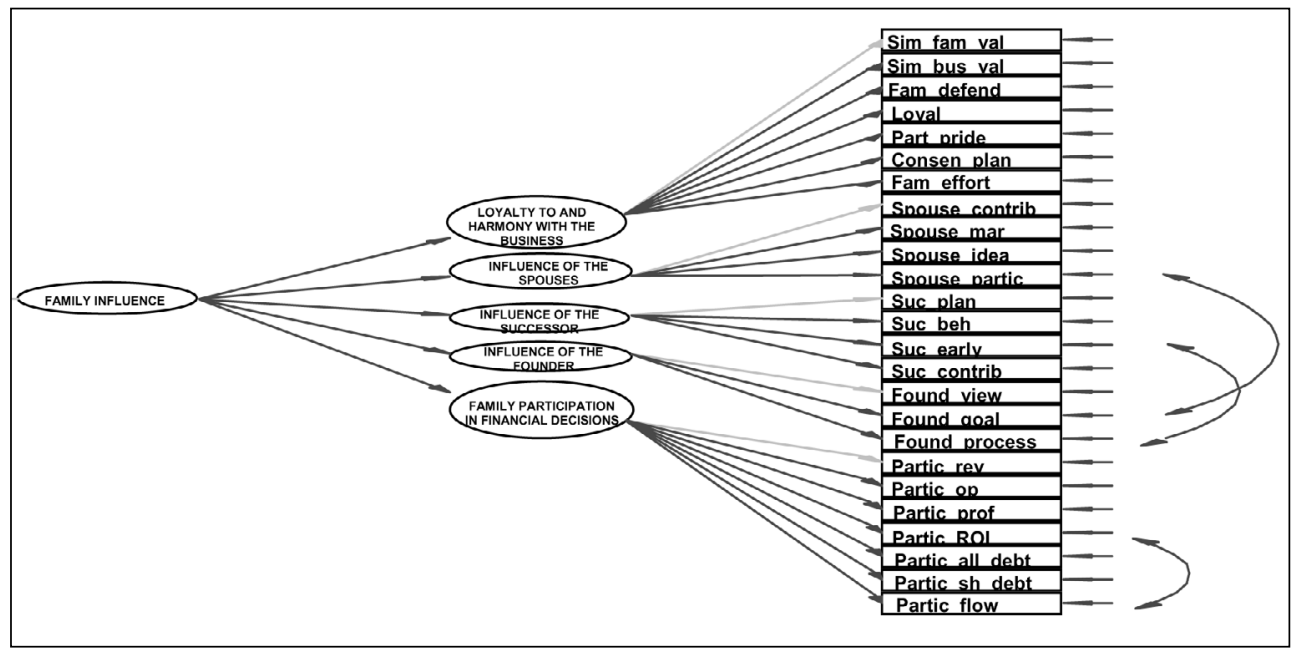

Source: own (formed by using the factors presented in Table 2)

Values of fit indices related to the model in Figure 2 are shown in Table 3.

\section{Tab. 3: $\quad$ Fit values for the detailed family influence model}

\begin{tabular}{|c|c|c|c|}
\hline Fit Index & Lower-Upper Limits & Values of the Model & Result \\
\hline $\begin{array}{l}\text { Root Mean Square Error } \\
\text { of Approximation (RMSEA) }\end{array}$ & $\begin{array}{c}\text { Good fit: RMSEA }<0.05 \\
\text { Acceptable fit: } 0.05 \leq \text { RMSEA } \leq 0.1\end{array}$ & 0.10 & Acceptable fit. \\
\hline Goodness of Fit Index (GFI) & $\begin{array}{c}\text { Good fit: } 0.95 \leq \mathrm{GFI} \leq 1.00 \\
\text { Acceptable fit: } 0.9<\mathrm{GFI}<0.95\end{array}$ & 0.91 & Acceptable fit. \\
\hline $\begin{array}{l}\text { Adjusted Goodness of Fit Index } \\
\text { (AGFI) }\end{array}$ & $\begin{array}{c}\text { Good fit: } 0.95 \leq \mathrm{AGFI} \leq 1.00 \\
\text { Acceptable fit: } 0.9<\mathrm{AGFI}<0.95\end{array}$ & 0.89 & Unacceptable fit. \\
\hline Comparative Fit Index (CFI) & $0.90 \leq \mathrm{CFI}$ & 0.99 & Good fit. \\
\hline $\begin{array}{l}\text { Expected Cross-validation Index } \\
\text { (ECVI) }\end{array}$ & $\begin{array}{l}\text { Good fit: ECVI value of the model } \\
\text { being lower than those of both the } \\
\text { independence model and the } \\
\text { saturated model. } \\
\text { Acceptable fit: ECVI value of the } \\
\text { model being lower than that of either } \\
\text { the independence model or the } \\
\text { saturated model. }\end{array}$ & $\begin{array}{c}\text { ECVI value of the } \\
\text { model is lower than } \\
\text { the ECVI values of } \\
\text { both the independence } \\
\text { model and the } \\
\text { satisfaction model. }\end{array}$ & Good fit. \\
\hline $\begin{array}{l}\text { Standardized Root Mean } \\
\text { Square Residual }\end{array}$ & $\begin{array}{l}\text { Standardized root mean square } \\
\text { residual }<0.05\end{array}$ & 0.097 & Unacceptable fit. \\
\hline
\end{tabular}

Source: own (calculations performed upon the family influence model in Figure 2) 
The good and acceptable fit measures in Table 3 were taken from the studies that suggest these limits (e.g. [21], [49]). When fit indices are considered, a detailed model of family influence becomes more realistic, as the model fits four of the foremost fit indices in the literature.

The five factors (see Table 2) that emerged on the basis of the SEM results can statistically be considered together under the main roof of family influence.
Conversely, eight variables from the EFA of the financial performance satisfaction variables were based on two factors. The KMO value was 0.877 , whereas the Bartlett test value was at the 0.05 level of significance; therefore, factor analysis is suitable to use on the variables. The total variance explained was $57.2 \%$. These two factors and their relevant variables are shown in Table 4.

\section{Tab. 4: Financial performance satisfaction factors and related variables}

\begin{tabular}{l|l|l|c}
$\begin{array}{c}\text { Sale-Operation Satisfaction } \\
\text { Factor }\end{array}$ & Factor Weight & \multicolumn{1}{|c|}{$\begin{array}{c}\text { Debt-Profit } \\
\text { Satisfaction Factor }\end{array}$} & Factor Weight \\
\hline Satisfaction with Sales Volume & 0.837 & Satisfaction with ROI & 0.769 \\
\hline Satisfaction with Operation Profitability & 0.576 & Satisfaction with Regular Cash Flows & 0.681 \\
\hline Satisfaction with Sales Revenue & 0.496 & Satisfaction with All Debt Reduction Activities & 0.700 \\
\hline & & Satisfaction with Short-term Debt Payment & 0.642 \\
\hline & & Satisfaction with Net Profit & 0.474 \\
\hline
\end{tabular}

Source: own (calculations performed upon the data collected from OIZs mentioned in Table 1)

Based on these results from the reliability analysis that considered Cronbach's alpha values, the reliability values of these two factors were 0.746 for satisfaction with sale-operation and 0.868 for satisfaction with debt-profit. The reliability value of all the variables was 0.891 .
Similar to the case of family influence, it was interesting to determine whether these two financial performance satisfaction factors could statistically be included under one overarching category. Thus, SEM was applied (Figure 3).

\section{Fig. 3: The financial performance satisfaction model}

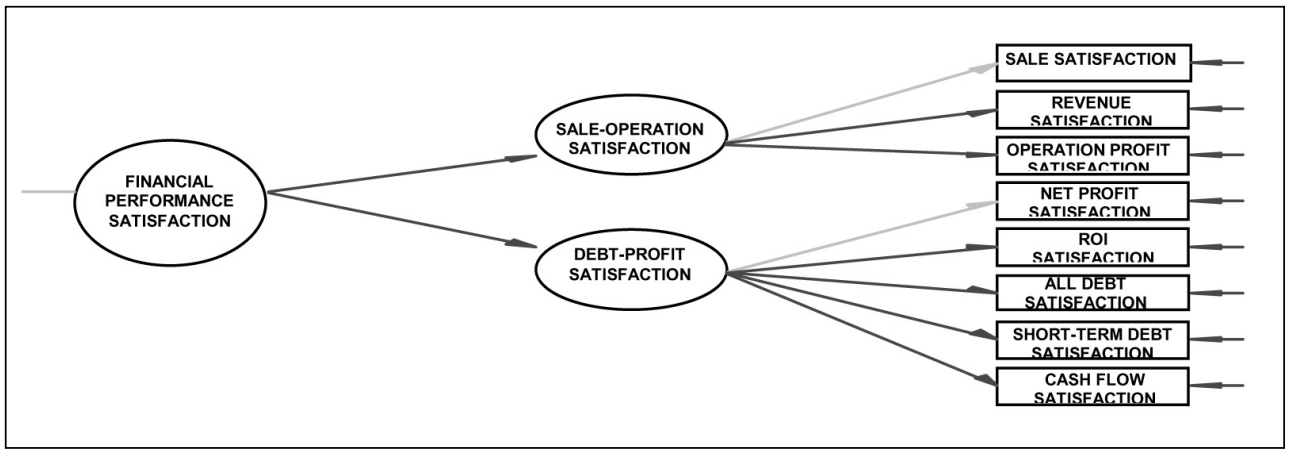

Source: own (formed by using the factors presented in Table 4)

The financial performance satisfaction model was found to be realistic based on the fit indices (Table 5). 


\section{Tab. 5: Fit values for the financial performance satisfaction model}

\begin{tabular}{|c|c|c|c|}
\hline Fit Index & Lower-Upper Limits & Values of the Model & Result \\
\hline RMSEA & $\begin{array}{c}\text { Good fit: RMSEA }<0.05 \\
\text { Acceptable fit: } 0.05 \leq \text { RMSEA } \leq 0.1\end{array}$ & 0.01 & Good fit. \\
\hline GFI & $\begin{array}{c}\text { Good fit: } 0.95 \leq \mathrm{GFI} \leq 1.00 \\
\text { Acceptable fit: } 0.9<\mathrm{GFI}<0.95\end{array}$ & 0.99 & Good fit. \\
\hline AGFI & $\begin{array}{c}\text { Good fit: } 0.95 \leq \mathrm{AGFI} \leq 1.00 \\
\text { Acceptable fit: } 0.9<\mathrm{AGFI}<0.95\end{array}$ & 0.99 & Good fit. \\
\hline CFI & $0.90 \leq \mathrm{CFI}$ & 1.00 & Good fit. \\
\hline ECVI & $\begin{array}{c}\text { Good fit: ECVI value of the model being } \\
\text { lower than those of both the } \\
\text { independence model and the saturated } \\
\text { model. } \\
\text { Acceptable fit: ECVI value of the model } \\
\text { being lower than that of either the } \\
\text { independence model or the saturated } \\
\text { model. }\end{array}$ & $\begin{array}{l}\text { ECVI value of the model is } \\
\text { lower than those of both the } \\
\text { independence model and the } \\
\text { satisfaction model. }\end{array}$ & Good fit. \\
\hline $\begin{array}{c}\text { Standardized Root } \\
\text { Mean Square } \\
\text { Residual }\end{array}$ & $\begin{array}{l}\text { Standardized root mean square residual } \\
\qquad<0.05\end{array}$ & 0.043 & Good fit. \\
\hline
\end{tabular}

Source: own (calculations performed upon the financial performance satisfaction model in Figure 3)

Based on the results from the SEM analysis, the concept of financial performance satisfaction is a combination of satisfaction with debt-profit and sale-operation.

At this point, the statistical structures of the family influence and financial performance satisfaction were obtained from the pilot study. From this point forward, the results of the investigation of the relationship between these two concepts will be presented.

\subsection{Results of the Relationship between Family Influence and Financial Performance Satisfaction}

A total of 410 questionnaires were used that were prepared on the basis of the structures obtained from the pilot study. Among these, information from 10 questionnaires was ignored due to significant errors and omissions. As a result, research was conducted in light of the data obtained from a total of 400 family businesses.

An analysis of the participant businesses based on their founding year indicated that the oldest business was founded in 1987 and that the newest was founded in 2008. In all of the businesses considered, the largest number of employees was 25 , and the smallest number was four. The average number of employees was 9.7, although businesses that employ 12 people predominated (75 total businesses). Both management and ownership were held by mostly first-generation family members, such that the average number of generations for management and ownership was found to be 1.33 and 1.31 , respectively. A striking observation was that none of the participant businesses was composed of or dated back three or more generations.

When the answers on the questionnaires were evaluated briefly, according to the top manager member of the family, none of the family members apart from the top manager participated, to any significant degree, in any of the financial decisions (average of variables for participation in financial decisions factor is 2.72). Although the results indicated that family is loyal to and harmonious with the business (average: 3.83 ), there was a general inconsistency noted in the results in terms of spousal influence on the business (average: 3.36). Successors were found to be more influential on the business than spouses (average: 3.62). 


\section{Business Administration and Management}

The most influential family member was the founder of the business (average: 3.9). Another important finding was that none of the participant businesses was satisfied with the financial performance of their business (average: 2.59).

Based on the pilot study, both the family influence and the financial performance satisfaction concepts are formed by a combination of different factors. It is, therefore, logical to investigate the relationships between both concepts as well as those between factors specific to each concept. Based on this, the relationship model proposed in Figure 1 is presented in more detail in Figure 4 after considering the statistical structures of each concept in the model.

\section{Fig. 4: Detailed relationship model}

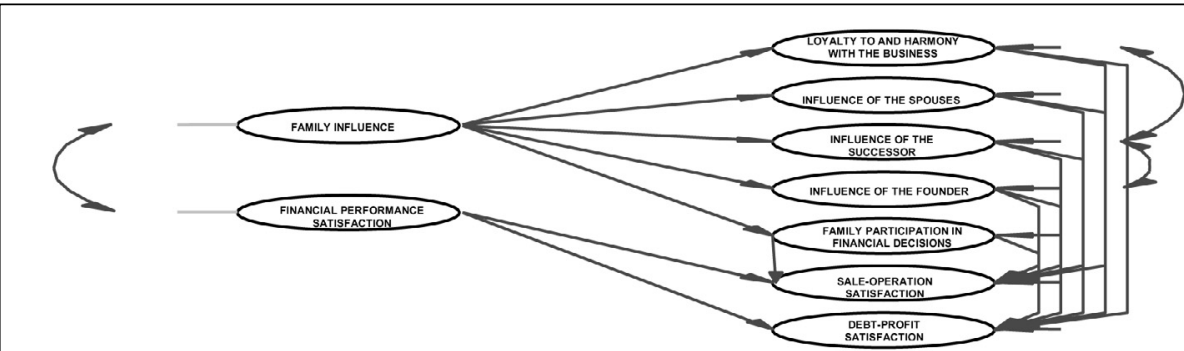

Source: own (adapted by the author based on the findings in Figures 1, 2 and 3)

Data in Table 6 reveal that the relationship model is realistic. The model fits the data collected as acceptable based on a majority of the foremost fit indices.

\section{Tab. 6: Fit values of the detailed relationship model}

\begin{tabular}{|c|c|c|c|}
\hline Fit Index & Lower-Upper Limits & Model Values & Result \\
\hline RMSEA & $\begin{array}{c}\text { Good fit: RMSEA }<0.05 \\
\text { Acceptable fit: } 0.05 \leq \text { RMSEA } \leq 0.1\end{array}$ & 0.089 & Acceptable fit. \\
\hline GFI & $\begin{array}{c}\text { Good fit: } 0.95 \leq \mathrm{GFI} \leq 1.00 \\
\text { Acceptable fit: } 0.9<\mathrm{GFI}<0.95\end{array}$ & 0.91 & Acceptable fit. \\
\hline AGFI & $\begin{array}{c}\text { Good fit: } 0.95 \leq \mathrm{AGFI} \leq 1.00 \\
\text { Acceptable fit: } 0.9<\mathrm{AGFI}<0.95\end{array}$ & 0.88 & Unacceptable fit. \\
\hline $\mathrm{CFI}$ & $0.90 \leq \mathrm{CFI}$ & 0.90 & Acceptable fit. \\
\hline ECVI & $\begin{array}{c}\text { Good fit: ECVI value of the model being } \\
\text { lower than those of both the independence } \\
\text { model and the saturated model. } \\
\text { Acceptable fit: ECVI value of the model } \\
\text { being lower than that of either the } \\
\text { independence model or the saturated } \\
\text { model. }\end{array}$ & $\begin{array}{l}\text { ECVI value of the model is } \\
\text { lower than that of the } \\
\text { independence model only. }\end{array}$ & Acceptable fit. \\
\hline $\begin{array}{l}\text { Standardized Root } \\
\text { Mean Square } \\
\text { Residual }\end{array}$ & $\begin{array}{l}\text { Standardized root mean square residual } \\
\qquad<0.05\end{array}$ & 0.093 & Unacceptable fit. \\
\hline
\end{tabular}

Source: own (calculations performed upon the detailed relationship model in Figure 4) 


\section{Ekonomika a management}

The model was accepted as statistically realistic; therefore, the relationships within the model can be investigated. Table 7 shows the relationships between family influence and financial performance satisfaction. These relationships were found to be statistically significant (for $p<0.05$ )

\section{Tab. 7: Correlations between the components of the detailed relationship model}

\begin{tabular}{l|c|c|c|c|c|c|c} 
& $\begin{array}{c}\text { Loyalty } \\
\text { to and } \\
\text { Harmony } \\
\text { with the } \\
\text { Business }\end{array}$ & $\begin{array}{c}\text { Influence } \\
\text { of the } \\
\text { Spouses }\end{array}$ & $\begin{array}{c}\text { Influence } \\
\text { of the } \\
\text { Successor }\end{array}$ & $\begin{array}{c}\text { Influence } \\
\text { of the } \\
\text { Founder }\end{array}$ & $\begin{array}{c}\text { Family } \\
\text { Participation } \\
\text { In Financial } \\
\text { Decisions }\end{array}$ & $\begin{array}{c}\text { Debt-Profit } \\
\text { Satisfaction }\end{array}$ & $\begin{array}{c}\text { Sale- } \\
\text { Operation } \\
\text { Satisfaction }\end{array}$ \\
\hline $\begin{array}{l}\text { Loyalty to and Harmony } \\
\text { with the Business }\end{array}$ & 1.00 & & & & & & \\
\hline Influence of the Spouses & 0.17 & 1.00 & & & & & \\
\hline Influence of the Successor & -0.05 & -0.03 & 1.00 & & & & \\
\hline Influence of the Founder & -0.28 & -0.05 & 0.16 & 1.00 & & & \\
\hline $\begin{array}{l}\text { Family Participation } \\
\text { In Financial Decisions }\end{array}$ & 0.12 & 0.02 & -0.02 & -0.03 & 1.00 & & \\
\hline Debt-Profit Satisfaction & 0.07 & 0.02 & -0.28 & 0.03 & -0.14 & 1.00 & \\
\hline Sale-Operation Satisfaction & 0.12 & -0.12 & -0.29 & -0.04 & -0.21 & 0.88 & 1.00 \\
\hline
\end{tabular}

Source: own (calculations performed upon the detailed relationship model in Figure 4)

According to Table 7, the following can be inferred:

- A strong and positive relationship between debt-profit satisfaction and sale-operation satisfaction is readily noted.

- Compared to the other family influence factors, there are positive correlations between successor influence and debt-profit satisfaction and sales operation satisfaction. There are inverse relationships between the influence of the successor and both types of satisfactions: when the successor influence increases, both types of satisfactions decrease.

- Compared to the other family influence factors, there is a strong relationship between the influence of the founder and loyalty to and harmony with the business. The remaining family influence factors have substantially weak interactions with one another.

- Increased participation of the family in financial decisions results in inverse relationships between debt-profit satisfaction and sales operation satisfaction.

According to the relationship model, family influence factors and financial performance satisfaction collectively affect both debt-profit satisfaction and sale-operation satisfaction. In other words, debt-profit satisfaction and saleoperation satisfaction factors of the model are influenced by other factors of the model. Thus, equations involving these influences should also be investigated within the scope of the relationship analysis. Debt_profit Sat $=0.31 *$ Loyalty and harmony $+0.0013^{*}$ Inf. of spouses $-0.32 *$ Inf. of succ. $+0.10^{*}$ Inf. of founder- $0.16 *$ Fam. Par. in fin. dec $+0.80 *$ Fin perf sat,
\[ \begin{array}{cccccc}(0.077) & (0.025) & (0.040) & (0.058) & (0.020) & (0.031) \\ 4.00 & 0.052 & -8.04 & 1.80 & -7.82 & 26.30\end{array} \] Errorvar. $=0.29, R^{2}=0.71$ (1)

(0.042)

6.86

Sale_operation Sat $=0.44 *$ Loyalty and harmony- $0.16^{*}$ Inf. of spouses- $0.33^{*}$ Inf. of succ. $+0.046^{*}$ Inf. of founder-0.23*Fam. Par. in fin. dec+1.00*Fin perf sat,

\begin{tabular}{|c|c|c|c|c|c|}
\hline$(0.088)$ & $(0.029)$ & $(0.039)$ & $(0.066)$ & (0.024) & $(0.039)$ \\
\hline 4.99 & -5.38 & -8.53 & 0.70 & -9.95 & 25.88 \\
\hline
\end{tabular}

Errorvar. $=0.11, R^{2}=0.61$

$-5.38$

$-8.53$

0.70

$-9.95$

25.88 
Upon examining equations (1) and (2), the first and interesting observation made was that the majority of the family influence factors are inversely related with debt-profit satisfaction and sales operation satisfaction. A detailed analysis of these relationships is presented in Table 8 . To summarize the analysis briefly, the data in Table 8 reveal that some family influence factors have statistically insignificant relationships with financial performance satisfaction factors, and in cases in which significant relationships are observed, some family influence factors affect financial performance satisfaction factors positively, whereas others do so negatively.

Results on the relationships between the components in the detailed relationship model (part 1)

\begin{tabular}{|c|c|c|c|c|}
\hline $\begin{array}{l}\text { Relationships between } \\
\text { Family Influence } \\
\text { Components and } \\
\text { Debt-Profit Satisfaction }\end{array}$ & $\begin{array}{c}\text { Coefficient for } \\
\text { the } \\
\text { Relationship }\end{array}$ & $\begin{array}{l}\text { Relationship } \\
\text { Coefficient's } \\
\text { t-value }\end{array}$ & $\begin{array}{l}\text { Is the } \\
\text { Relationship } \\
\text { Significant? }\end{array}$ & CONCLUSION \\
\hline $\begin{array}{l}\text { Loyalty to and Harmony } \\
\text { with the Business AND } \\
\text { Debt-Profit Satisfaction }\end{array}$ & 0.31 & 4.00 & YES & $\begin{array}{l}\text { As loyalty to and harmony with the } \\
\text { business increases, top manager family } \\
\text { members become more satisfied with the } \\
\text { debt-profit aspects of the business. }\end{array}$ \\
\hline $\begin{array}{l}\text { Spouse Influence AND } \\
\text { Debt-Profit Satisfaction }\end{array}$ & 0.0013 & 0.052 & NO & $\begin{array}{l}\text { The relationship is statistically } \\
\text { insignificant. }\end{array}$ \\
\hline $\begin{array}{l}\text { Successor Influence AND } \\
\text { Debt-Profit Satisfaction }\end{array}$ & -0.32 & -8.04 & YES & $\begin{array}{l}\text { As the influence of the successor } \\
\text { ncreases, top manager family members } \\
\text { become less satisfied with the debt-profit } \\
\text { aspects of the business. }\end{array}$ \\
\hline $\begin{array}{l}\text { Founder Influence AND } \\
\text { Debt-Profit Satisfaction }\end{array}$ & 0.10 & 1.80 & NO & $\begin{array}{l}\text { The relationship is statistically } \\
\text { insignificant. }\end{array}$ \\
\hline $\begin{array}{l}\text { Participation of the Family } \\
\text { in Financial Decisions AND } \\
\text { Debt-Profit Satisfaction }\end{array}$ & -0.16 & -7.82 & YES & $\begin{array}{l}\text { As family participation in financial } \\
\text { decisions increases, top manager family } \\
\text { members become less satisfied with the } \\
\text { debt-profit aspects of the business. }\end{array}$ \\
\hline $\begin{array}{l}\text { General: Family Influence } \\
\text { Components AND } \\
\text { Debt-Profit Satisfaction }\end{array}$ & \multicolumn{4}{|c|}{$\begin{array}{l}\text { Spouses and founder do not have significant influences on satisfaction with the debt-profit } \\
\text { aspect of the business. In addition, all remaining family influence components, excluding } \\
\text { loyalty to and harmony with business, adversely affect satisfaction with the debt-profit aspect } \\
\text { of the business. }\end{array}$} \\
\hline $\begin{array}{l}\text { Loyalty to and Harmony } \\
\text { with the Business AND } \\
\text { Sale-Operation Satisfaction }\end{array}$ & 0.44 & 4.99 & YES & $\begin{array}{l}\text { As loyalty to and harmony with business } \\
\text { grows stronger, top manager family } \\
\text { members become more satisfied with the } \\
\text { sales operation aspects of the business. }\end{array}$ \\
\hline $\begin{array}{l}\text { Spouse Influence AND } \\
\text { Sale-Operation Satisfaction }\end{array}$ & -0.16 & -5.38 & YES & $\begin{array}{l}\text { As spouse influence increases, top } \\
\text { manager family members become less } \\
\text { satisfied with the sales operation aspects } \\
\text { of the business. }\end{array}$ \\
\hline $\begin{array}{l}\text { Successor Influence AND } \\
\text { Sale-Operation Satisfaction }\end{array}$ & -0.33 & -8.53 & YES & $\begin{array}{l}\text { As successor influence increases, top } \\
\text { manager family members become less } \\
\text { satisfied with the sales operation aspects } \\
\text { of the business. }\end{array}$ \\
\hline $\begin{array}{l}\text { Founder Influence AND } \\
\text { Sale-Operation Satisfaction }\end{array}$ & 0.046 & 0.70 & NO & $\begin{array}{l}\text { The relationship is statistically } \\
\text { insignificant. }\end{array}$ \\
\hline
\end{tabular}




\section{Ekonomika a management}

Tab. 8:

Results on the relationships between the components in the detailed relationship model (part 2)

\begin{tabular}{l|c|c|c|c}
$\begin{array}{l}\text { Relationships between } \\
\text { Family Influence } \\
\text { Components and } \\
\text { Debt-Profit Satisfaction }\end{array}$ & $\begin{array}{c}\text { Coefficient for } \\
\text { the } \\
\text { Relationship }\end{array}$ & $\begin{array}{c}\text { Relationship } \\
\text { Coefficient's } \\
\text { t-value }\end{array}$ & $\begin{array}{c}\text { Is the } \\
\text { Relationship } \\
\text { Significant? }\end{array}$ & CONCLUSION \\
\hline $\begin{array}{l}\text { Participation of the Family } \\
\text { in Financial Decisions AND }\end{array}$ & -0.23 & -9.95 & YES & $\begin{array}{l}\text { As family participation in financial } \\
\text { decisions increases, top manager family } \\
\text { members become less satisfied with the } \\
\text { sale-Operation Satisfaction operation aspects of the business. }\end{array}$ \\
$\begin{array}{l}\text { General: Family Influence } \\
\text { Components AND } \\
\text { Sale-Operation Satisfaction }\end{array}$ & $\begin{array}{l}\text { Founder does not have a significant influence on satisfaction with the sales operation aspect } \\
\text { of the business. All remaining family influence components, excluding loyalty to and harmony } \\
\text { with the business, inversely affect satisfaction with the sales operation aspect of the business. }\end{array}$ \\
\hline
\end{tabular}

Source: own (calculations performed upon the detailed relationship model in Figure 4)

Finally, Table 9 shows the relationship between family influence and financial performance satisfaction as a whole. Based on these results, there is a weak inverse relationship between influence and satisfaction. Therefore, the satisfaction of the top member family member with the financial performance of his or her business decreases as family influence increases.

\section{Tab. 9:}

Relationship between family influence and satisfaction with financial performance based on the detailed relationship model

\begin{tabular}{l|c|c|c|l}
$\begin{array}{l}\text { Family Influence } \\
+\end{array}$ & $\begin{array}{l}\text { Correlation } \\
\text { Coefficient } \\
\text { Satisfancial Performance }\end{array}$ & $\begin{array}{c}\text { Correlation } \\
\text { Coefficient's } \\
\text { t-value }\end{array}$ & $\begin{array}{c}\text { Is the } \\
\text { Relationship } \\
\text { Significant? }\end{array}$ & CONCLUSION \\
\hline & -0.26 & -6.50 & YES & $\begin{array}{l}\text { There is a weak inverse relationship } \\
\text { between family influence and satisfaction } \\
\text { of the top manager family member with } \\
\text { the financial performance of his or her } \\
\text { business. }\end{array}$ \\
\hline
\end{tabular}

Source: own (calculations performed upon the detailed relationship model in Figure 4)

\section{Conclusions, Comments and Suggestions}

Studies on family businesses address a variety of topics, and in all of these studies, the existence of two systems is noticeable: family and business. However, in a majority of these studies, family businesses are evaluated similar to any other businesses; in other words, the general approach observed is that the natural presence of family-business relationships in family businesses can easily be ignored.

Indeed, few studies on family businesses in the literature have investigated the relationship between family and business as their main topic. The purpose of this article was to emphasize precisely this much ignored family- business relationship. As a result, these findings contribute to the recent literature on similar topics. In nearly all of the studies that scrutinized the family-business relationship, there is an expectation that family members or family-specific topics will influence the business in some way.

Findings from this article, which were prepared with the above expectation as the point of departure, indicate that the majority of the factors that constitute family influence can indeed affect the level of satisfaction that the top manager family member feels with business-specific matters; more specifically, with the financial performance of the business. The successor's influence on the business and participation of the family in financial decisions 
were found to diminish the satisfaction felt by the manager with debt-profit aspects of the business. Conversely, spouses and founders of the businesses were not found to be influential on the satisfaction that the top manager family member felt with the debt-profit aspects of the business. The only factor that increased the satisfaction that the manager felt with the debtprofit aspects of the business was loyalty to and harmony with the business.

When the satisfaction of the top manager family member with the sales operation aspect of the business was examined, the founder of the business was not influential. In addition, excluding loyalty to and harmony with the business, all other family influence factors negatively affected the relative satisfaction that the top manager member of the family felt with the financial performance of his or her business.

The main conclusion from this research is that there is a weak inverse relationship between the influence of the family and satisfaction with financial performance.

A general assessment in light of the conclusions reached is that the top manager member of the family is displeased, in terms of financial performance of the business, with his or her spouse, successor of the business, or any other family members when they try to intervene with business issues. This assessment appears logical, as most of the businesses that participated in this research were firstgeneration family businesses as mentioned previously. It is possible that in these businesses, the founder and/or owner of the business, in general, is/are expected to take control over the business. This person may avoid sharing control of the business with other family members.

This avoidance may stem from a reluctance to share power with others. For instance, the top manager member of the family may believe that his spouse or successor of the business is incapable of managing the business, or he or she may hesitate to engage other family members in management roles for fear of creating conflict.

The factor of loyalty to and harmony with the business was found to positively influence both factors of financial performance satisfaction. According to this finding, regarding the financial aspect of the business, the top manager member of the family is pleased with his or her family when they express pride in the business, defend the business, demonstrate effort in the business, and align their value judgments with those of the business. The author believes that the reason explaining this pleasure is reflected in the variables used in this research. When spousal and successor influences were investigated, some of the expressions related to these influences were found to be associated directly with control over the business. However, within the factor of loyalty to and harmony with the business, none of the family members used expressions pertaining to control over the business.

In short, when the financial performance of the business is considered, while the top manager family member is uncomfortable with acts by other family members, such as the spouse and successor, in becoming involved in control over the business, he feels pleased with his family members when they show loyalty to and act in harmony with the business.

The reasons explaining the role played by the founder of the business in satisfaction with financial performance arise from the characteristics of the participant businesses. The majority of the participant businesses were first-generation family businesses. As such, the founder and top manager may be expected by many businesses to be the same person. In addition, participants are not pleased with the financial performance of their businesses. An interpretation of this situation is that the founders, who constitute the majority of the participants, believe that the financial performance of their businesses is poor but that they are not responsible for this situation.

The last component of family influence is that of family participation in financial decisions. This factor negatively affected the financial performance satisfaction factors; in other words, not only is the top manager family member uncomfortable with the inclination of other family members towards taking control over the business, but he or she is also displeased with them when they participate in financial decisions.

In family businesses, the influence that family has on the business should be regarded as a natural characteristic of the business. In future studies, family influence can be considered an intervening (or explanatory) variable. For example, family influence can be an intervening variable in relationships between family business strategies and financial 
performance. Additionally, when environment factors are reflected in the business, family will step in and act in such a way as to change or moderate the influence of the factors on the business. To state it differently, family will serve as a filter when environment factors influence the business. Each of these examples can become subjects of separate studies.

In addition, family influence can be used as a dependent variable (or group of factors). In such a case, issues that result in family influence can be investigated first. The first of such issues is managerial issues. It is also possible that relationships between family members can influence decisions regarding the business. If family businesses in different locations are being researched, the effect of sectoral, regional, and even cultural differences on family influence can be investigated. In cases in which the family influence factor is considered a dependent component, how this influence changes with time can also be investigated. Research on the types of family-related changes that occur over time and how these changes affect family influence is another possible area of interest. In this respect, a life curve approach can be used in the evaluation of family influence.

In conclusion, the influence of the family on the family business is a relatively new concept, one that has rarely been investigated directly. In addition, only a handful of studies in the literature have discussed the impact of family influence on the business when considering either a variety of factors or a single issue. Conversely, family influence can be approached in conjunction with several different types of topics and with different mentalities. Accordingly, more in-depth research on the subject of family business is essential.

\section{References}

[1] ADSAN, E., GUMUSTEKIN, G.E. $A$ research about applications of family constitution and family council in publicly traded companies. Paper presented at the Istanbul Kultur University 2nd Congress On Family Businesses. Istanbul, April 2006.

[2] ALCARAZ, J.A. Family influence on financial performance satisfaction in Mexican family businesses. San Diego (CA), 2004. 278 p. Dissertation thesis. Alliant International University, California School of Business and Organizational Studies.
[3] ANDERSON, R.C., MANSI, S.A., REEB, D.M. Founding family ownership and the agency cost of debt. Journal of Financial Economics. 2003, Vol. 68, Iss. 2, pp. 263-285. ISSN 0304-405X.

[4] ANDERSON, R.C., REEB, D.M. Foundingfamily ownership and firm performance: Evidence from the S\&P 500. Journal of Finance. 2003, Vol. 58, Iss. 3, pp. 1301-1328. ISSN 0022-1082.

[5] ANG, J.S., COLE, R.A. and LIN, J.W. Agency costs and ownership structure. Journal of Finance. 2000, Vol. 55, Iss. 1, pp. 81-106. ISSN 0022-1082. [6] ASTRACHAN, J.H., KLEIN, S.B. and SMYRNIOS, K.X. The F-PEC scale of family influence: A proposal for solving the family business definition problem. Family Business Review. 2002, Vol. 15, Iss. 1, pp. 45-58. ISSN 0894-4865.

[7] ATHANASSIOU, N., CRITTENDEN, W.F., KELLY, L.M., MARQUEZ, P. Founder centrality effects on the Mexican family firms' top management group: Firm culture, strategic vision and goals and firm performance. Journal of World Business. 2002, Iss. 37, Iss. 2, pp. 139-150. ISSN 1090-9516.

[8] ATLI, H. An application on the views of young generations about institutionalization at family businesses. Izmir, 2007. Master's thesis. Dokuz Eylul University.

[9] AYRANCI, E. The influence of family at family businesses and a research on its relationship with financial performance satisfaction. Istanbul, 2009. Doctoral dissertation. İstanbul University.

[10] BARNES, L.B., HERSHON, S.A. Transferring power in the family business. Family Business Review. 1989, Vol. 2, Iss. 2, pp. 187-202. ISSN 0894-4865.

[11] BARRY, B. The development of organizational structure in the family firm. Family Business Review. 1989, Vol. 2, Iss. 3, pp. 293-315. ISSN 0894-4865.

[12] BAS, M., ARTAR, A. Inspection of efficiency in businesses. MPM publications no. 435: Ankara, 1991.

[13] BERGSTROM, T.C. A fresh look at the Rotten Kid Theorem and other household mysteries. Journal of Political Economy. 1989, Vol. 97, Iss. 5, pp. 1138-1159. ISSN 0022-3808.

[14] BILGIN, N. Inclinations of family businesses to institutionalization: Ankara SME sample. Ankara, 2007. Master's thesis. Atilim University. [15] CHRISMAN, J.J., CHUA, J.H. and LITZ, R.A. Comparing the agency cost of family and nonfamily firms: Conceptual issues and exploratory 
evidence. Entrepreneurship Theory and Practice. 2004, Vol. 28, Iss. 4, pp. 335-354. ISSN 1042-2587. [16] CHURCHILL, N.C., HATTEN, K.J. Nonmarket based transfers of wealth and power: A research framework for family businesses. American Journal of Small Business. 1987, Vol. 11, Iss. 3, pp. 51-64. ISSN 0363-9428.

[17] CLIFF, J.E. and JENNINGS, P.D. Commentary on the multidimensional degree of family influence construct and the F-PEC measurement instrument. Entrepreneurship Theory and Practice. 2005, Vol. 29, Iss. 3, pp. 341-347. ISSN 1042-2587.

[18] DAILY, C.M. and DOLLINGER, M.J. An empirical examination of ownership structure in family and professionally managed firms. Family Business Review. 1992, Vol. 5, Iss. 2, pp. 117-136. ISSN 0894-4865.

[19] DANNHAEUSER, N. The survival of familyoperated firms under developed conditions: The case of Hassfurt, Germany. The Journal of Developing Areas. 1993, Vol. 27, Iss. 3, pp. 307-328. ISSN 0022-037X.

[20] DAVIS, P. Realizing the potential of the family business. Organizational Dynamics. 1983, Vol. 12, Iss. 1, pp. 47-56. ISSN 0090-2616.

[21] DIAMANTOPOULOS, A., SIGUAW, J. Introducing LISREL. A Guide for the Uninitiated. SAGE Publications, 2000. 171 p. ISBN 9780761951711. [22] DI POFI, J.A. Effects of family influence on satisfaction with financial performance in family businesses. Auburn (Alabama), 2003. Doctoral dissertation. Auburn University.

[23] DONCKELS, R., FRÖHLICH, E. Are family businesses really different? European experiences from stratos. Family Business Review. 1991, Vol. 4, Iss. 2, pp. 149-160. ISSN 0894-4865.

[24] DYER, W.G., HANDLER, W. Entrepreneurship and family business: Exploring the connections. Entrepreneurship Theory and Practice. 1994, Vol. 19, Iss. 1, pp. 71-83. ISSN 1042-2587.

[25] GARCIA-ALVAREZ, E., LOPEZ-SINTAS, J., GONZALVO, P.S. Socialization patterns of successors in first to second generation family businesses. Family Business Review. 2002, Vol. 15, Iss. 3, pp. 189-204. ISSN 0894-4865.

[26] GOLDBERG, S.D. Research note: Effective successors in family-owned business: Significant elements. Family Business Review. 1996, Vol. 9, Iss. 2, pp. 185-197. ISSN 0894-4865.

[27] GUNDRY, L.K., WELSCH, H.P. Differences in familial influence among women-owned businesses. Family Business Review. 1994, Vol. 7, Iss. 3, pp. 273-286. ISSN 0894-4865.
[28] HANDLER, W.C. Succession in family firms: A mutual role adjustment between entrepreneur and next-generation family members. Entrepreneurship Theory and Practice. 1990, Vol. 15, Iss. 1, pp. 37-51. ISSN 1042-2587.

[29] IKITELLI OIZ. Firm guide [online]. [cit. 201103-04]. Available from: http://www.iosb.org.tr/ v2/firmalar.xls.

[30] ISTANBUL BEYLIKDUZU OIZ. Firms [online]. [cit. 2011-03-04]. Available from: http://www.ibosb. com/TR/firm.

[31] ISTANBUL DUDULLU OIZ. Enterprizes in the zone [online]. [cit. 2011-03-04]. Available from: http://www.idosb.org.tr/bolgedekikuruluslar.asp.

[32] ISTANBUL LEATHER OIZ. Firm catalogue [online]. [cit. 2011-03-04]. Available from: http://www.ideriosb.org.tr/index.php?option=com sobi2\&ltemid $=18$.

[33] ISTANBUL TUZLA OIZ. The list of all firms [online]. [cit. 2011-03-04]. Available from: http://www.itosb.org.tr/tumfirma.htm.

[34] ISTANBUL TUZLA PAINT AND LECQUER OIZ. Firms [online]. [cit. 2011-03-04]. Available from: http://www.boyavernikosb.com/firmalar.htm.

[35] JAFFE, D.T. Strategic planning for the family in business. Journal of Financial Planning. 2005, Vol. 18, Iss. 3, pp. 50-56. ISSN 1040-3981.

[36] KARPUZOGLU, E. Family constitution for the future. Paper presented at Istanbul Kultur University 1st Congress On Family Businesses April 2004. Istanbul, 2004.

[37] KAYE, K. Mate selection and family business success. Family Business Review. 1999, Vol. 12, Iss. 2, pp. 107-115. ISSN 0894-4865.

[38] KLEIN, S.B., ASTRACHAN, J.H., SMYRNIOS, K.X. The F-PEC scale of family influence: Construction, validation and further implication for theory. Entrepreneurship Theory and Practice. 2005, Vol. 29, Iss. 3, pp. 321-339. ISSN 1042-2587. [39] KOBIEFOR. Tuzla chemical enterprises [online]. [cit. 2011-03-04]. Available from: http://www.kobi-efor.com.tr/haber_detay.asp?id= 2647.

[40] KURATKO, D.F. Family business succession in Korean and U.S. Firms. Journal of Small Business Management. 1993, Vol. 31, Iss. 2, pp. 132-136. ISSN 0047-2778.

[41] LACHAPELLE, K., BARNES, L.B. The trust catalyst in family-owned businesses. Family Business Review. 1998, Vol. 11, Iss. 1, pp. 1-17. ISSN 0894-4865.

[42] LITZ, R.A. The family firm's exclusion from business school research: Explaining the void; 
addressing the opportunity. Entrepreneurship Theory and Practice. 1997, Vol. 21, Iss. 3, pp. 55-71. ISSN 1042-2587.

[43] MATEAR, S., CADOGAN, J.W., HOOLEY, G. First steps towards an internationally invariant measure of firm performance. Paper presented at ANZMAC 2003 Conference December 2003. Adelaide, 2003.

[44] MCCONAUGHY, D.L., MATTHEWS, C.H., FIALKO, A.S. Founding family controlled firms: Efficiency, risk and value. Journal of Small Business Management. 2001, Vol. 39, Iss. 1, pp. 31-50. ISSN 0047-2778.

[45] PERVAIZ, A.K., KWANG, L.K., MOHAMED, Z. Measurement practice for knowledge management. Journal of Workplace Learning. 1999, Vol. 11, Iss. 8, pp. 304-311. ISSN 1366-5626.

[46] PONTET, S.B., WROSCH, C., GAGNE, M. An exploration of the generational differences in levels of control held among family businesses approaching succession. Family Business Review. 2007, Vol. 20, Iss. 4, pp. 337-354. ISSN 0894-4865.

[47] POZA, E.J., MESSER, T. Spousal leadership and continuity in the family firm. Family Business Review. 2001, Vol. 14, Iss. 1, pp. 25-35. ISSN 0894-4865.

[48] RUE, L.W., IBRAHIM, N.A. The status of planning in smaller family-owned business. Family Business Review. 1996, Vol. 9, Iss. 1, pp. 29-44. ISSN 0894-4865.

[49] SCHERMELLEH-ENGEL, K., MOOSBRUGGER, H. Evaluating the fit of Structural Equation Models: Tests of significance and descriptive goodness-of-fit measures. Methods of Psychological Research. 2003, Vol. 8, Iss. 2, pp. 23-74. ISSN 1616-8119.

[50] SCHULZE, W.S., LUBATKIN, M.H., DINO, R.N., BUCHHOLTZ, A.K. Agency relationship in family firms: Theory and evidence. Organization Science. 2001, Vol. 12, Iss. 9, pp. 99-116. ISSN 1047-7039.

[51] SHANKER, M.C., ASTRACHAN, J.H. Myths and realities: Family businesses' contribution to the U.S. Economy - a framework for assessing family business statistics. Family Business Review. 1996, Vol. 9, Iss. 2, pp. 107-122. ISSN 0894-4865.
[52] SRAER, D., TESHMAR, D. Performance and behavior of family firms: Evidence from the french stock market. ECGI - Finance Working Paper No.130/2006 [online]. January, 2006 [cit. 2011-03-04]. Available from: http://ssrn.Com/abstract=925415.

[53] THE FREE DICTIONARY. Satisfaction [online]. [cit. 2011-01-07]. Available from: http://www.thefreedictionary.com/satisfaction.

[54] THE HIGHER COUNCIL OF ORGANIZED INDUSTRIAL ZONES. [online]. [cit. 2011-03-04]. Available from: http://www.osbuk.org/index.php? page $=$ content $/$ osbler\&id $=1$.

[55] TUZLA MARBLE OIZ. Tuzla marble OIZ active firms [online]. [cit. 2011-03-04]. Available from: http://www.tmosb.com/dosyalar/faalliste.xls.

[56] VERA, C.F. and DEAN, M.A. An examination of the challenges daughters face in family business succession. Family Business Review. 2005, Vol. 18, Iss. 4, pp. 321-345. ISSN 0894-4865.

[57] VON BUCH, S.D. The relationship of family influence, top management teams' behavioral integration and firm performance in German family businesses. San Diego (CA), 2006. Doctoral dissertation (DBA). Alliant International University, Marshall Goldsmith School of Management.

[58] WARD, J.L., DOLAN, C. Defining and describing family business ownership configurations. Family Business Review. 1998, Vol. 11, Iss. 4, pp. 305-310. ISSN 0894-4865.

[59] WESTHEAD, P., HOWORTH, C. Ownership and management issues associated with family firm performance and company objectives. Family Business Review. 2006, Vol. 19, Iss. 4, pp. 301-316. ISSN 0894-4865.

[60] ZAHRA, S.A. International expansion of U.S. Manufacturing family businesses: The effect of ownership and involvement. Journal of Business Venturing. 2003, Vol. 18, Iss. 4, pp. 495-512. ISSN 0883-9026.

Assoc. Prof. Dr. Evren Ayranci Istanbul AREL University Faculty of Economics and Administrative Sciences xonox@mynet.com 


\section{Abstract}

\section{A STUDY ON THE INFLUENCE OF FAMILY ON FAMILY BUSINESSES AND ITS RELATIONSHIP TO SATISFACTION WITH FINANCIAL PERFORMANCE Evren Ayranci}

This article investigated, within family businesses, the theoretical and practical relationships between the influence of family on the family business and the satisfaction of the top manager family member with the financial performance of his or her business. How a family can influence its own business and what is meant by satisfaction with financial performance has been examined on the basis of the extant literature. Questionnaires have been created regarding the influence of family and satisfaction with financial performance. Afterwards, the relationship between influence and satisfaction was examined within the scope of a proposed model. Data were collected from the family businesses located in the organized industrial zones of Istanbul, Turkey. The influence of family and the satisfaction of the top manager family member with financial performance were found to be based on five and two key factors, respectively. In view of the findings, although spouses of the family members within the family business did not influence satisfaction with profit or debt, they did cause a decrease in satisfaction with sales and operations. The involvement of family in the financial decisions along with the business successor also negatively affected satisfaction with debt, profit, sales, and operations. Although the founder of the business did not have a significant influence on the factors that affected satisfaction with financial performance, family members' loyalty to and harmony with the business positively affected satisfaction with financial performance. In conclusion, the influence of family has a weak inverse relationship with top manager family member's financial performance satisfaction.

Key Words: Family businesses, management, influence of family, financial performance.

JEL Classification: M10.

DOI: 10.15240/tul/001/2014-2-007 